\title{
Is the risk of preeclampsia higher in donor oocyte pregnancies? A systematic review and meta-analysis
} \author{
Ricardo Pommer ${ }^{2}$ \\ ${ }^{1}$ Clinical Departament of Obstetrics and Gynecology, Universidad de Santiago, Chile \\ 2 Unit of Reproductive Medicine, Clínica Monteblanco, Santiago, Chile \\ ${ }^{3}$ School of Dentistry, Universidad de los Andes, Santiago, Chile \\ ${ }^{4}$ Unit of Reproductive Medicine, Clínica Las Condes, Santiago, Chile
}

Juan Enrique Schwarze ${ }^{1,2}$, Paula Borda ${ }^{1}$, Pamela Vásquez ${ }^{3}$, Carolina Ortega ${ }^{2}$, Sonia Villa ${ }^{2}$, Javier A. Crosby ${ }^{4}$,

\begin{abstract}
Objective: Preeclampsia (PE) occurs in $4.6 \%$ of pregnancies worldwide. The social phenomenon of increasing maternal age has raised the demand for donor oocytes. Egg donation has allowed women with poor ovarian reserve, premature ovarian failure, genetic disorders or surgical menopause to get pregnant. Recipients provide a unique model of immune response because of the differences in the genetic makeup of mothers and fetuses. In PE, immune tolerance may be impaired as a result of having non-autologous eggs implanted. Egg donation is a highly successful assisted reproductive technology, despite the significant number of issues arising from the implantation of non-autologous eggs. This study aimed to determine whether there is an association between egg donation and preeclampsia.

Methods: A systematic review of the literature available in PubMed and Google Scholar was carried out from January of 1995 to August of 2016 using the terms 'oocyte donation, preeclampsia', 'oocyte donation, in vitro fertilization, preeclampsia', 'oocyte donation, preeclampsia, outcomes pregnancies', 'oocyte donation, obstetric outcome.' Only six retrospective cohort studies met the selection criteria.

Result: The meta-analysis revealed a statistically significant association between egg donation and onset of preeclampsia (OR 4.50; 95\% CI: 3.28-6.19; $p<0.0001$ ).

Conclusion: Oocyte donation is associated with increased risk of preeclampsia in singleton pregnancies. Therefore, it is crucial to properly record and assess this finding when egg donation is the chosen assisted reproductive technology to attain pregnancy.
\end{abstract}

Keywords: oocyte donation, preeclampsia, in vitro fertilization

\section{INTRODUCTION}

Estimates indicate that $4.6 \%$ of all pregnancies are complicated by pre-eclampsia (PE). Incidence varies depending on maternal age and on whether the mother is in her first pregnancy (Hutcheon et al., 2011). Maternal age and the number of donor oocyte procedures have increased steadily in recent years (Berkowitz et al., 1993; Ferraretti et al., 2013).

Egg recipients provide a unique model of immune response because of the differences in the genetic makeup of mothers and fetuses (Levron et al., 2014). The presence of an immune component in the etiology of preeclampsia has been suggested. While in pregnancies without PE there is a certain tolerance for foreign antigens, in the presence of preeclampsia immune tolerance is hampered in cases of non-autologous egg implantation (Redman \& Sargent, 2010).
Many issues have been described in donor egg pregnancies (Van der Hoorn et al., 2010). Previous studies have shown inconsistent results when comparisons were made between complications of in-vitro fertilization (IVF) procedures with and without donor oocytes, for reasons ranging from small simple sizes to inadequate control groups ( $A b-$ dalla et al., 1998; Krieg et al. 2008; Wiggins \& Main 2005).

The purpose of this systematic review and meta-analysis was to determine whether donor oocyte pregnancies have higher incidences of preeclampsia when compared to IVF using autologous oocytes.

\section{MATERIAL AND METHODS}

\section{Search}

The search for literature was performed in MEDLINE via PubMed and Google Scholar (January 1995 to August 2016) using combinations of the terms "oocyte donation, preeclampsia", "oocyte donation, in vitro fertilization, preeclampsia", "oocyte donation, preeclampsia, outcomes pregnancies", "oocyte donation, obstetric outcome" in all search fields. Only papers written in English were included.

\section{Study selection}

Cohort studies were eligible for inclusion in the review. Case reports, case series, and secondary studies were excluded. Studies comparing IVF, using donor eggs or autologous oocytes, were selected for inclusion. Women aged 35 to 49 years with singleton pregnancies and diagnosed with preeclampsia were eligible for inclusion. Studies enrolling patients with gestational hypertension and PE occurring concurrently were excluded.

\section{Data extraction}

Two independent unmasked reviewers screened all potentially relevant papers for their titles and abstracts, and retrieved full texts only for the papers meeting the selection criteria. Disagreements were resolved with the involvement of a third reviewer (CO). The references of the selected papers were searched for additional studies. Data was extracted by one of the authors (PB) using a standardized extraction form that included number of cases with and without PE and in vitro fertilization pregnancies with or without donor eggs.

\section{Synthesis of studies}

Studies were combined using a fixed-effect model. The statistical analysis included $2 \times 2$ contingency tables, from which ORs and their 95\% confidence intervals were calculated for donor oocyte pregnancies using the Peto method. Meta-analysis was performed with Stata 11.0 (Statacorp, USA). Additionally, results were shown in a forest plot. Heterogeneity was evaluated using the $\mathrm{I}^{2}$ test and Cochrane's Q test. Heterogeneity was considered significant when $p<0.1$ and $\mathrm{I}^{2}>40 \%$. 


\section{RESULTS}

The search retrieved 193 papers. After manually excluding duplicates, 114 articles remained for screening by title and abstract. Only 18 studies remained for full text revision. Eight studies were excluded because their samples comprised women with multiple pregnancies (Simeone et al., 2012; Klatsky et al., 2010; Le Ray et al. 2012; Söderström-Anttila et al., 1998; Tranquilli et al. 2013; Wiggins \& Main 2005; Michalas et al., 1996; Henne et al., 2007); one was excluded due to undifferentiated diagnosis of PE with gestational hypertension (Jeve et al., 2016); two did not record the number of singleton pregnancies with PE (Corradetti et al., 2012; Krieg et al., 2008); and one had a study group that was not homogeneous for oocyte donation (Porreco et al., 2005). Additionally, references from the selected papers were checked for new unidentified studies. In the end, six papers meeting the inclusion criteria were considered in the meta-analysis (Nejdet et al., 2016; Van Dorp et al., 2014; Levron et al., 2014; Malchau et al., 2013; Stoop et al., 2012; Salha et al., 1999). The included papers featured retrospective cohort studies. The risk of PE was adjusted for maternal age and parity; in two studies, additional adjustments were made for fetal gender (Malchau et al., 2013; Stoop et al., 2012); and in one study adjustments were made for tobacco use and BMI (Nejdet et al., 2016).

The six selected studies evinced an association between donor oocytes and preeclampsia (PE) (37,994 pregnancies with 111 donor oocytes). Nejdet et al. (2016) included cases from 2003 to 2012 from in vitro fertilization clinics. In the donor oocyte group, $13.14 \%(51 / 338)$ had $P E$, whereas in the control group $4.14 \%(1.105 / 26.696)$ presented PE (OR 9.059; 95\% confidence interval (CI): 5.518-14.874). Van Dorp et al. (2014) included cases from the Dutch Perinatal Register between 1992 and 2009. In the donor oocyte group, $13.11 \%(8 / 61)$ presented $P E$, while $10.94 \%$ (21/192) presented PE in the control group (OR 1.238; 95\% CI: $0.502-$ 3.053). Levron et al. (2014) included cases from 2005 to 2011. In the donor oocyte group, 9.35\% (13/139) showed $\mathrm{PE}$, while in the control group $4.76 \%(6 / 126)$ had PE (OR 1.99; 95\% CI: 0.782-5.052). Malchau et al. (2013) studied cases from 1995 to 2010 from the Danish IVF register. In the donor oocyte group, $9.76 \%(21 / 215)$ had PE whereas in the control group $3.21 \%(316 / 9.833)$ had PE (OR 7.55 ; $95 \% \mathrm{CI}$ : 3.565-15.993). Stoop et al. (2012) analyzed cases from the Brussels center for reproductive medicine between 1999 and 2008. In the donor oocyte group, 15 of 148 patients (10.13\%) had preeclampsia (OR 1.930; 95\% CI: 0.825- 4.515). Salha et al. (1999) investigated cases at the St. James's University Hospital in Leeds. In the donor oocyte group, $13.63 \%(3 / 22)$ had $\mathrm{PE}$, versus $3.8 \%(1 / 26)$ in the control group (OR 3.51 ; 95\% CI: $0.459-26.781$ ) (Table 1).

Preeclampsia was present in $11.5 \%$ of the pregnant patients with donor oocytes $(n=111)$, versus $3.9 \%(n=1,457)$ of the individuals with autologous oocytes. After the meta-analysis, women who conceived using donor oocytes showed a significant increment in the risk of preeclampsia (RR 2.62; 95\% CI: 2.13-3.21) (Figure 1). In general, heterogeneity across studies was assessed as not relevant $(p=0.175 ; \mathrm{I} 2=34.9 \%)$.

\begin{tabular}{|c|c|c|c|}
\hline Author, year & Methods & Participants, period & Findings \\
\hline Nejdet, 2016 & Retrospective cohort study & $\begin{array}{l}\text { Women from IVF Swedish clinics, } \\
\text { from } 2003 \text { to } 2012\end{array}$ & $\begin{array}{l}\text { Donor oocyte group consisted of } \\
388 \text { patients, } 51 \text { with PE }(13.14 \%) \text {. } \\
\text { In the control group, } 1,105 / 26,696 \\
(4.14 \%) \text { had PE. OR } 9.059(95 \% \\
\text { CI:5.518 to } 14.874) \text {. Weight: } 41.31 .\end{array}$ \\
\hline $\begin{array}{l}\text { Van Dorp, } \\
2014\end{array}$ & Retrospective cohort study & $\begin{array}{l}\text { Women from the Dutch Perinatal } \\
\text { Register, from } 1992 \text { to } 2009\end{array}$ & $\begin{array}{l}\text { Study group consisted of } 61 \text { patients } \\
\text { with singleton pregnancies. } 8 \text { out of } \\
61 \text { had PE }(13.11 \%) \text {. The control } \\
\text { group had } 21 / 192(10.94 \%) \text { cases } \\
\text { of PE. OR } 1.238(95 \% \text { CI: } 0.502 \text { to } \\
3.053) \text {. Weight } 12.47 .\end{array}$ \\
\hline Levron, 2014 & Retrospective cohort study & From 2005 to 2011. & $\begin{array}{l}13 \text { of } 139 \text { patients in the donor oo- } \\
\text { cyte group had PE }(9.35 \%) \text {. In the } \\
\text { autologous oocyte group, } 6 \text { of } 126 \\
\text { had PE ( } 4.76 \%) \text {. OR } 1.988 \text { ( } 95 \% \\
\text { CI: } 0.782 \text { to } 5.052) \text {. Weight } 11.67 \text {. }\end{array}$ \\
\hline $\begin{array}{l}\text { Malchau, } \\
2013\end{array}$ & Retrospective cohort study & $\begin{array}{l}\text { Women from the Danish in vitro fer- } \\
\text { tilization register, from } 1995 \text { to } 2010 \text {. }\end{array}$ & $\begin{array}{l}\text { The donor oocyte group included } 215 \\
\text { patients and } 21 \text { cases of PE }(9.76 \%) \text {. } \\
\text { Control group had } 316 / 9.833 \\
(3.21 \%) \text { with PE. OR } 7.551(95 \% \\
\text { CI:3.565 to } 15.993) \text {. Weight } 18.03 .\end{array}$ \\
\hline Stoop, 2012 & Retrospective cohort study & $\begin{array}{l}\text { Matched pair-analysis for age, eth- } \\
\text { nicity, parity and plurality from } \\
\text { the Centre for Reproductive Medi- } \\
\text { cine,Brussels. Data obtained from } \\
1999 \text { to } 2008 \text {. }\end{array}$ & $\begin{array}{l}\text { Donor oocyte had } 15 \text { of } 148 \text { pregnant } \\
\text { women diagnosed with PE (10.13\%). } \\
\text { Control group had } 8 \text { of } 148(5.4 \%) \\
\text { with PE. OR } 1.930(95 \% \text { CI:0.825 to } \\
\text { 4.515). Weight } 14.07 .\end{array}$ \\
\hline Salha, 1999 & Retrospective cohort study & $\begin{array}{l}\text { Women from St. James's University } \\
\text { Hospital, Leeds(UK), from } 1992 \text { to } \\
1997\end{array}$ & $\begin{array}{l}\text { Donor oocyte group had } 3 \text { of } 22 \text { pa- } \\
\text { tients diagnosed with PE ( } 13.63 \% \text { ). } \\
\text { In the control group, only } 1 \text { pregnant } \\
\text { woman of } 26 \text { was diagnosed with PE } \\
(3.8 \%) \text { OR } 3.508 \text { ( } 95 \% \text { CI: } 0.459 \\
\text { to } 26.781 \text { ). Weight } 2.46 \text {. }\end{array}$ \\
\hline
\end{tabular}




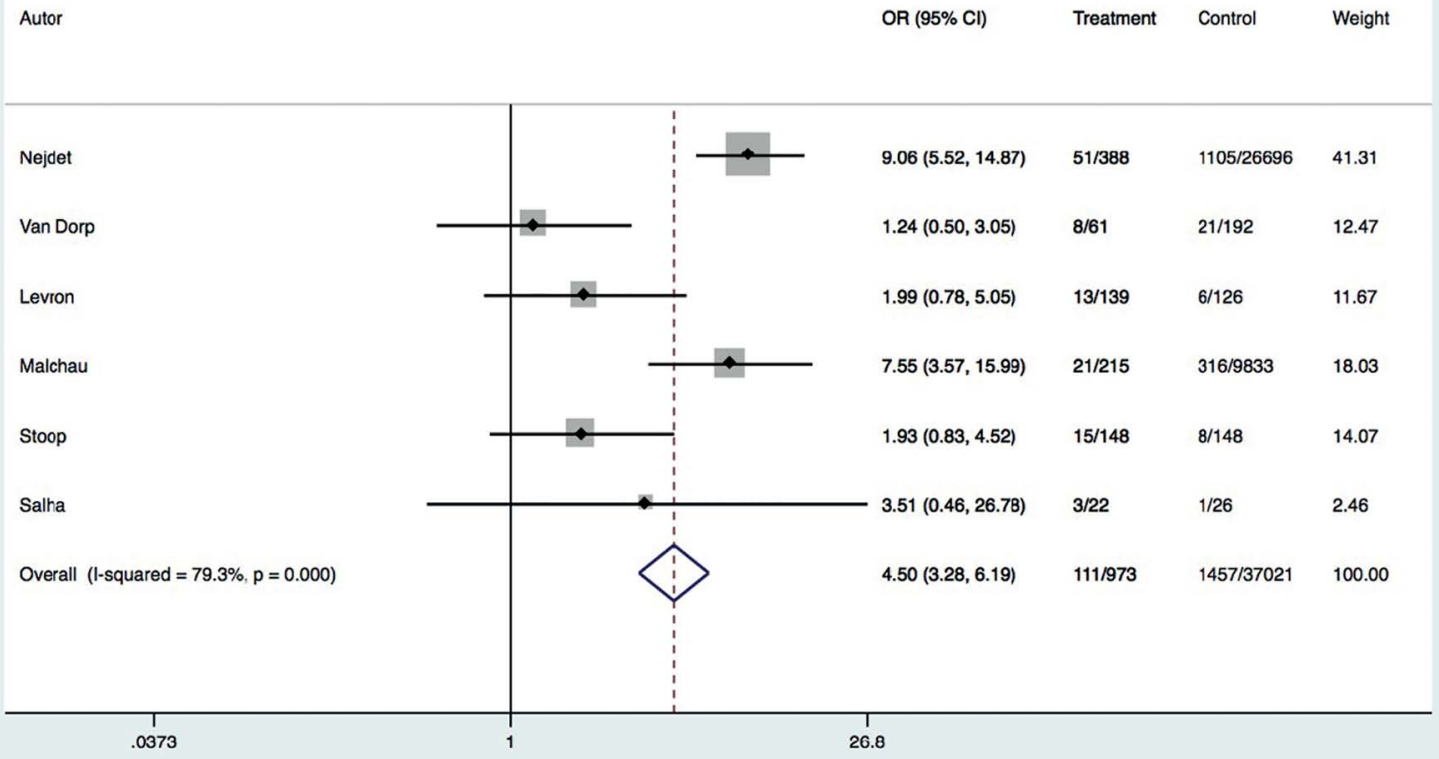

Figure 1. Forest plot

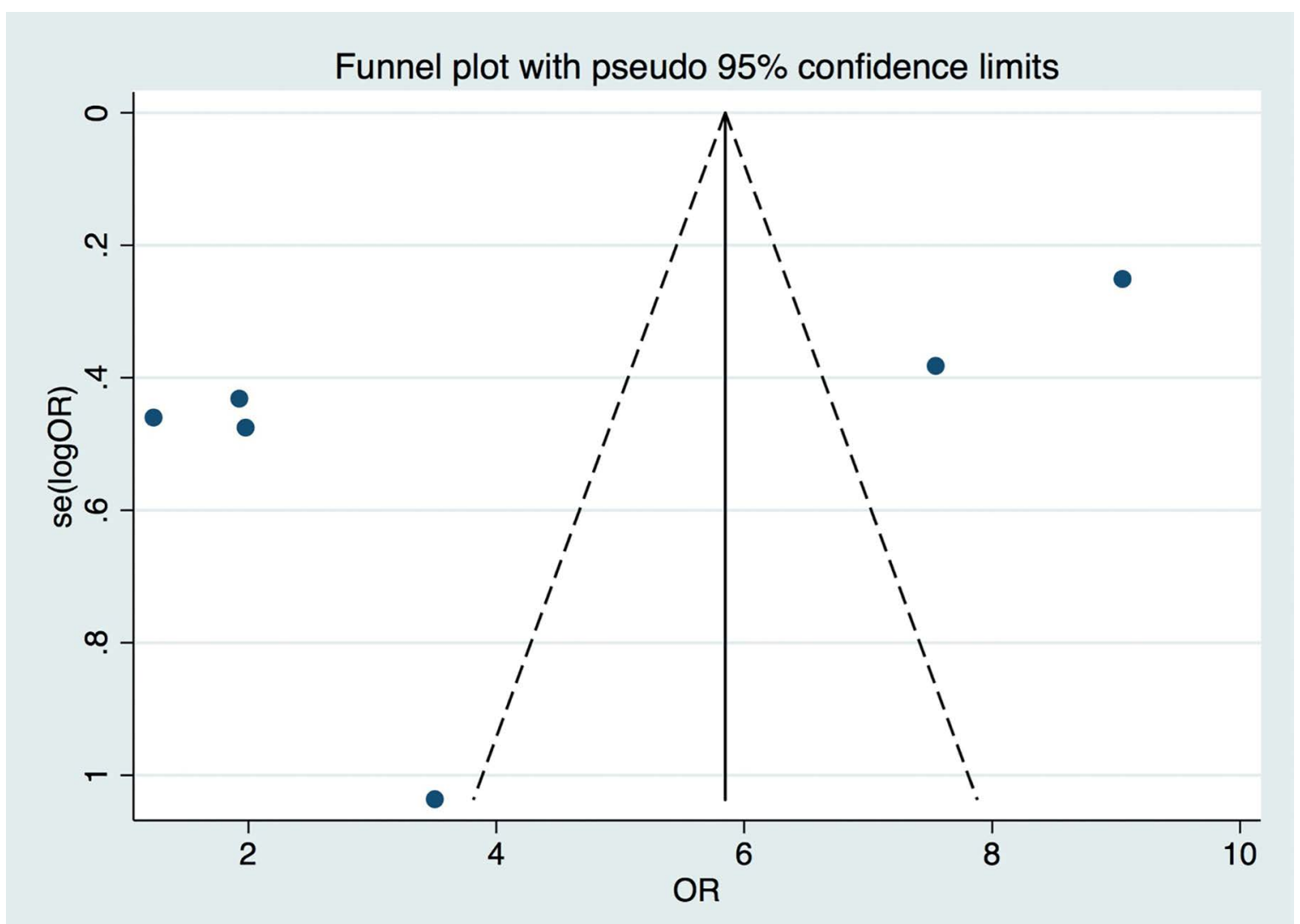

Figure 2. Funnel Plot 
Publication bias was assessed using a funnel plot (Figure 2), and significant scatter of effect size and study size was found in both directions.

\section{DISCUSSION}

The purpose of this systematic review and meta-analysis was to determine whether donor oocyte pregnancies were associated with increased risk of preeclampsia. In this review, a summary of six articles comparing the frequency of preeclampsia according to oocyte origin - autologous or donor - was performed. The findings revealed a significant increase in preeclampsia when donor oocytes were used.

A major strength of this study was that it focused exclusively on studies that compared IVF patients with oocyte origin as the variable of interest. Another important feature to be considered is that only singleton pregnancies were incorporated; maternal age and parity were accounted for in the analysis. A study limitation is the lack of information on the underlying causes for choosing of IVF with or without donor eggs, since the etiology of infertility might have been an independent risk factor for preeclampsia. All included papers featured retrospective cohort studies, which lack methodological robustness.

The etiology of preeclampsia in donor oocyte pregnancies is yet to be clarified. An immune theory has been postulated based on the allogenicity of the fetus in relation to the mother. In the implantation phase of pregnancy, the uterine decidua is invaded by trophoblast cells expressing HLA-C, a ligand of the immunoglobulin-type receptor of natural killer (NK) cells. NK cells facilitate the neovascularization of the decidua through proangiogenic and endothelial factors, which in turn modulate the adaptive changes of the uterine spiral arteries (Blázquez et al., 2016). When this process unfolds appropriately, adequate blood flow to the fetus is guaranteed. Fetal HLA-C differs from maternal HLA-C because it contains paternal alleles. When a donor egg is used, fetal HLA-C is even less recognizable by the maternal immune system, as it is completely allogeneic. This can disturb the blood flow to the placenta and, in turn, facilitate the onset of certain disorders such as preeclampsia and intrauterine growth restriction (Klatsky et al., 2010; Madeja et al., 2011; Hiby et al., 2004). The role of acetylsalicylic acid in preeclampsia prevention in women given donor oocytes is yet to be elucidated.

The evidence summarized in this paper revealed an association between oocyte origin and incidence of preeclampsia in singleton pregnancies from IVF. We believe that this study will allow physicians and patients to make informed decisions about the fertilization procedures available needed to attain reproductive success.

\section{CONFLICT OF INTERESTS}

No conflict of interest has been declared.

\section{Corresponding author:}

Juan Enrique Schwarze,

Department of Obstetrics and Gynecology, Universidad de Santiago

Unit of Reproductive Medicine, Clínica Monteblanco

Santiago, Chile

E-mail: jeschwarze@gmail.com

\section{REFERENCES}

Abdalla HI, Billett A, Kan AK, Baig S, Wren M, Korea L, Studd JW. Obstetric outcome in 232 ovum donation pregnancies. Br J Obstet Gynaecol. 1998;105:332-7. PMID: 9532996 DOI: $10.1111 / \mathrm{j} .1471-0528.1998 . t b 10096 . x$
Berkowitz GS, Skovron ML, Lapinski RH, Berkowitz RL. Does delayed childbearing increase risk? JAMA. 1993;269:745-6. PMID: 8423649DOI: 10.1001/jama.1993.03500060045020

Blázquez A, García D, Rodríguez A, Vassena R, Figueras $F$, Vernaeve $V$. Is oocyte donation a risk factor for preeclampsia? A systematic review and meta-analysis. J Assist Reprod Genet. 2016;33:855-63. PMID: 27007875 DOI: $10.1007 / \mathrm{s} 10815-016-0701-9$

Corradetti A, Talebi Chahvar S, Biondini V, Giannubilo SR, Tranquilli AL. PP093 Maternal and fetal outcomes in oocyte donor pregnancies. Pregnancy Hypertens. 2012;2:2901. PMID: 26105415 DOI: 10.1016/j.preghy.2012.04.204

Ferraretti AP, Goossens V, Kupka M, Bhattacharya S, de Mouzon J, Castilla JA, Erb K, Korsak V, Nyboe Andersen A; European IVF-Monitoring (EIM) Consortium for the European Society of Human Reproduction and Embryology (ESHRE). Assisted reproductive technology in Europe, 2009: results generated from European registers by ESHRE. Hum Reprod. 2013;28:2318-31. PMID: 23842560 DOI: $10.1093 /$ humrep/det278

Henne MB, Zhang M, Paroski S, Kelshikar B, Westphal LM. Comparison of obstetric outcomes in recipients of donor oocytes vs. women of advanced maternal age with autologous oocytes. J Reprod Med. 2007;52:585-90. PMID: 17847755

Hiby SE, Walker JJ, O'Shaughnessy KM, Redman CW, Carrington M, Trowsdale J, Moffett A. Combinations of maternal KIR and fetal HLA-C genes influence the risk of preeclampsia and reproductive success. J Exp Med. 2004;200:957-65. PMID: 15477349 DOI: $10.1084 /$ jem.20041214

Hutcheon JA, Lisonkova S, Joseph KS. Epidemiology of preeclampsia and the otherhypertensive disorders of pregnancy. Best Pract Res Clin Obstet Gynaecol. 2011;25:391-403. PMID: 21333604 DOI: 10.1016/j.bpobgyn.2011.01.006

Jeve YB, Potdar N, Opoku A, Khare M. Three-arm age-matched retrospective cohort study of obstetric outcomes of donor oocyte pregnancies. Int J Gynaecol Obstet. 2016;133:156-8. PMID: 26892692 DOI: $10.1016 /$ j.ijgo.2015.09.024

Klatsky PC, Delaney SS, Caughey AB, Tran ND, Schattman GL, Rosenwaks Z. The role of embryonic origin in preeclampsia: a comparison of autologous in vitro fertilization and ovum donor pregnancies. Obstet Gynecol. 2010;116:1387-92. PMID: 21099607 DOI: $10.1097 /$ AOG.0b013e3181fb8e59

Krieg SA, Henne MB, Westphal LM. Obstetric outcomes in donor oocyte pregnancies compared with advanced maternal age in in vitro fertilization pregnancies. Fertil Steril. 2008;90:65-70. PMID: 17727845 DOI: $10.1016 /$ j.fertnstert.2007.06.014

Le Ray C, Scherier S, Anselem O, Marszalek A, Tsatsaris V, Cabrol D, Goffinet F. Association between oocyte donation and maternal and perinatal outcomes in women aged 43 years or older. Hum Reprod. 2012;27:896-901. PMID: 22252087 DOI: 10.1093/humrep/der469 
Levron Y, Dviri M, Segol I, Yerushalmi GM, Hourvitz A, Orvieto R, Mazaki-Tovi S, Yinon Y. The 'immunologic theory' of preeclampsia revisited: a lesson from donor oocyte gestations. Am J Obstet Gynecol. 2014;211:383. e1-5. PMID: 24657130 DOI: 10.1016/j.ajog.2014.03.044

Madeja Z, Yadi H, Apps R, Boulenouar S, Roper SJ, Gardner L, Moffett A, Colucci F, Hemberger M. Paternal MHC expression on mouse trophoblast affects uterine vascularization and fetal growth. Proc Natl Acad Sci U S A. 2011;108:4012-7. PMID: 21300875 DOI: $10.1073 /$ pnas. 1005342108

Malchau SS, Loft A, Larsen EC, Aaris Henningsen AK, Rasmussen S, Andersen AN, Pinborg A. Perinatal outcomes in 375 children born after oocyte donation: a Danish national cohort study. Fertil Steril. 2013;99:1637-43. PMID: 23465822 DOI: 10.1016/j.fertnstert.2013.01.128

Michalas $S$, Loutradis D, Drakakis $P$, Milingos $S$, Papageorgiou J, Kallianidis K, Koumantakis E, Aravantinos D. Oocyte donation to women over 40 years of age: pregnancy complications. Eur J Obstet Gynecol Reprod Biol. 1996;64:175-8. PMID: 8819998 DOI: $10.1016 / 0301-2115(95) 02335-6$

Nejdet S, Bergh C, Källén K, Wennerholm UB, ThurinKjellberg A. High risks of maternal and perinatal complications in singletons born after oocyte donation. Acta Obstet Gynecol Scand. 2016;95:879-86. PMID: 27060438 DOI: 10.1111 /aogs. 12904

Porreco RP, Harden L, Gambotto M, Shapiro H. Expectation of pregnancy outcome among mature women. Am J Obstet Gynecol. 2005;192:38-41. PMID: 15672000 DOI: 10.1016/j.ajog.2004.07.035

Redman CW, Sargent IL. Immunology of pre-eclampsia. Am J Reprod Immunol. 2010;63:534-43. PMID: 20331588 DOI: $10.1111 / \mathrm{j} .1600-0897.2010 .00831 . \mathrm{x}$

Salha O, Sharma V, Dada T, Nugent D, Rutherford AJ, Tomlinson AJ, Philips S, Allgar V, Walker JJ. The influence of donated gametes on the incidence of hypertensive disorders of pregnancy. Hum Reprod. 1999;14:2268-73. PMID: 10469693 DOI: $10.1093 /$ humrep/14.9.2268
Simeone S, Rambaldi MP, Ottanelli S, Serena C, Mello G, Mecacci F. PP109. Risk of preeclampsia in homologous and oocyte donation IVF pregnancies. Pregnancy Hypertens. 2012;2:298. PMID: 26105431 DOI: $10.1016 /$ j.preghy.2012.04.220

Söderström-Anttila V, Tiitinen A, Foudila T, Hovatta $O$. Obstetric and perinatal outcome after oocyte donation: comparison with in-vitro fertilization pregnancies. Hum Reprod. 1998;13:483-90. PMID: 9557862 DOI: $10.1093 /$ humrep/13.2.483

Stoop D, Baumgarten M, Haentjens P, Polyzos NP, De Vos $M$, Verheyen $G$, Camus M, Devroey P. Obstetric outcome in donor oocyte pregnancies: a matched-pair analysis. Reprod Biol Endocrinol. 2012;10:42. PMID: 22672289 DOI: $10.1186 / 1477-7827-10-42$

Tranquilli AL, Biondini V, Talebi Chahvar S, Corradetti A, Tranquilli D, Giannubilo S. Perinatal outcomes in oocyte donor pregnancies. J Matern Fetal Neonatal Med. 2013;26:1263-7. PMID: 23421425 DOI: 10.3109/14767058.2013.777422

van der Hoorn ML, Lashley EE, Bianchi DW, Claas FH, Schonkeren CM, Scherjon SA. Clinical and immunologic aspects of egg donation pregnancies: a systematic review. Hum Reprod Update. 2010;16:704-12. PMID: 20543201 DOI: $10.1093 /$ humupd/dmq017

van Dorp W, Rietveld AM, Laven JS, van den Heuvel-Eibrink MM, Hukkelhoven CW, Schipper I. Pregnancy outcome of non-anonymous oocyte donation: a case-control study. Eur J Obstet Gynecol Reprod Biol. 2014;182:107-12. PMID: 25268777 DOI: 10.1016/j.ejogrb.2014.09.019

Wiggins DA, Main E. Outcomes of pregnancies achieved by donor egg in vitro fertilization--a comparison with standard in vitro fertilization pregnancies. Am J Obstet Gynecol. 2005;192:2002-8. PMID: 15970875 DOI: $10.1016 /$ j.ajog.2005.02.059 